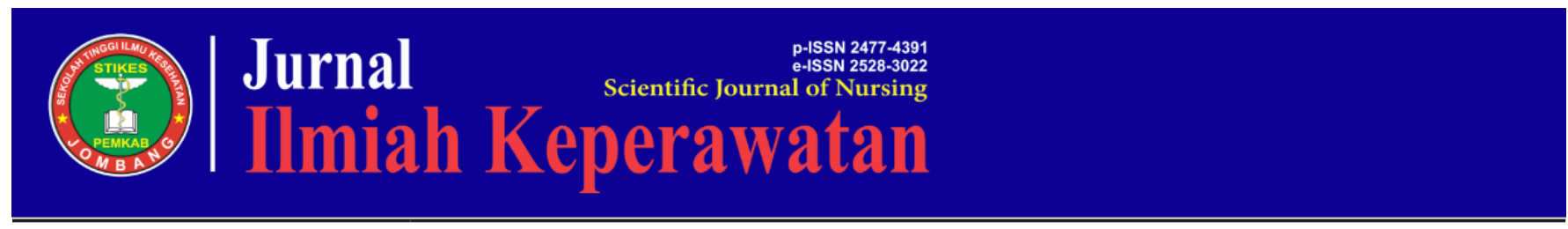

\title{
ANALISIS FAKTOR YANG BERHUBUNGAN DENGAN PERUBAHAN TEKANAN DARAH POST HEMODIALISIS DI RSUD KABUPATEN INDRAMAYU
}

\author{
Wayunah 1, Muhammad Saefulloh ${ }^{2}$
}

1.Stikes Indramayu, Jawa Barat

2. Stikes Indramayu, Jawa Barat

\section{Riwayat artikel}

Diajukan: 07 Juli 2021

Diterima: 20 Juli 2021

\section{Email Korespondensi:} wayunah.stikesindramayu@gmail.com

\section{Kata Kunci:}

Age, Change Of Blood Pressure, Duration Of Hemodialysis, Interdialityc Weight Gain, Quick Of Blood

\begin{abstract}
Introduction: The changes of blood pressure, that can be increasing or decreasing, occur during hemodialysis therapy due to some factors. Those factors that can influence the changes of blood pressure in post-hemodialysis are patient characteristics, age, Interdialityc Weight Gain (IDWG), Quick of Blood (QoB) and duration of hemodialysis. The purpose of this study is to know the factors associated with changes of blood pressure in post-hemodialysis in CKD patients that has undergone routine hemodialysis in the UPTD of Indramayu Public Hospital.
\end{abstract}

Methods: This research is a descriptive-analysis and uses a cross-sectional approach. It has taken 123 respondents that were selected based on consecutive sampling techniques. Its instrument used observation sheets and aneroid sphygmomanometers which data were analyzed with the Pearson Chi-Suare test.

Result: The result shows that 108 respondents (87.8\%) experienced changes of blood pressure, both increasing and decreasing, while 15 respondents (12.2\%) did not experience changes of blood pressure (constant). The rest of them, 64 repsondents $(52 \%)$, experienced a decreasing of blood pressure in post-hemodialysis. Age factor ( $\mathrm{p}$-value $=$ 0.604; 95\% CI); IDWG (p-value = 0.144; 95\% CI); QoB (p-value = 0.767; 95\% CI); and duration of hemodialysis ( $\mathrm{p}$-value $=0.506 ; 95 \% \mathrm{CI}$ ) was not related to changes of blood pressure and direction of post-hemodialysis.

Conclusion And Suggestion: There are no factors that affect changes of blood pressure in post-hemodialysis. For further research on changes of blood pressure, it is suggested that the research needs to be done by considering other factors that may affect changes of blood pressure, and uses the right method to find dominant factors that influence changes of blood pressure in post-hemodialysis. 


\section{PENDAHULUAN}

Penyakit ginjal kronik (PGK) merupakan penyakit yang ditandai dengan adanya penumpukan cairan dan uremia serta penurunan laju filtrasi glomerulus di dalam darah akibat menurunnya fungsi ginjal. Kondisi tersebut dapat mengancam keselamatan hidup penderitanya sehingga dapat menimbulkan kematian (Smeltzer dan Bare, 2015; Black \& Hawk, 2014).

Angka kejadian penyakit ginjal kronik semakin tahun semakin bertambah. Menurut World Health Organization (WHO), penyakit ginjal kronik berkontribusi pada beban penyakit dunia dengan angka kematian sebesar 850.000 jiwa per tahun. Menurut data Indonesia Renal Registry (IRR, 2018) menunjukan bahwa setiap tahun 200.000 orang menderita penyakit ginjal kronis. Hasil data Riset Kesehatan Dasar (Rikesdas) tahun 2013 tercatat sekitar $0,2 \%$ penduduk Indonesia yang menderita PGK dan jumlah tersebut meningkat pada tahun 2018 menjadi 0,38\%. Artinya bahwa ada kenaikan jumlah pasien PGK dari tahun 2013 sampai dengan 2018 sebanyak 0,18\% (Badan Penelitian dan Pengembangan Kesehatan, 2018)

Tahap end stage renal failure memerlukan terapi penggantiginjal. Terapi pengganti ginjal yang diketahui ada dua jenis yaitu peritonialdialisa dan hemodialisa (Saferi \& Mariza, 2013). Berdasarkan Indonesian Renal Registry (IRR, 2016), sebanyak 98\% penderita gagal ginjal menjalani terapi hemodialisa, dan sisanya tidak mendapatkan pelayanan hemodialisa.

Perubahan tekanan darah dapat terjadi selama menjalani terapi hemodialisa. Perubahan tersebut meliputi peningkatan atau penurunan tekanan darah. Menurut Van Buren, Kim, Toto, and Inrig (2011), kejadian hipertensi intradialitik sekitar 5 sampai $15 \%$. Hal tersebut diperkirakan terjadi karena (1) kelebihan cairan, (2) mekanisme system renin angiotensin, (3) kehilangan obat hipertensi selama hemodialisa, (4) disfungsi endotel, dan (5) ketidakseimbangan elektrolit termasuk kandungan natrium, kalsium dan kalium dlaam dialisat.

Menurut Assimon and Flythe (2015) mengatakan bahwa pengukuran tekanan darah interdialitik dilakukan untuk memastikan keselamatan pasien selama menjalani hemodialisa. Berdasarkan hasil studinya menunjukkan ada hubungan antara hipotensi, hipertensi, dan variasi tekanan darah lainnya dengan kematian. Van Buren (2017) mengatakan bahwa sebagian besar studi epidemiologi menemukan terjadi peningkatan tekanan darah sebesar $5-10 \mathrm{mmHg}$ (pre dan post hemodialisa) selama periode 1 minggu sampai 3 bulan.

Ada banyak faktor yang mempengaruhi perubahan teranan darah interdialisis. Faktor usia, interdialytic weight gain, ureum reduction ratio, lama hemodialisa, dan dosis quick of blood diperkirakan mempengaruhi perubahan tekanan darah interdialisis. Hasil studi yang dilakukan oleh Flythe, Kunaparaju, Dinesh, Kathriyn, et al (2012) mnemukan bahwa usia yang lebih tua dan dialysis yang lebih lama dipercaya sebagai faktor yang berhubungan dengan perubahan tekanan darah sistolik. Sedangkan karakteristik pasien lainnya tidak. Penarikan cairan yang besar juga dikaitkan dengan perubahan tekanan darah interdialitik.

Adekuasi hemodialisa dipercaya memegang peranan penting dalam mempengaruhi tekanan darah. Seperti halnya dengan Quick of blood (QoB) yang menjadi salah satu indicator adekuasi hemodialisa. QoB adalah jumlah darah yang dapat dialirkan dalam satuan menit (ml/menit) (Daugirdas, Blake \& Ing, 2007). Menurut PERNEFRI (2008) mengatakan bahwa adekuasi dosis quick of blood pada pasien berbeda-beda, tergantung dari kondisi klinis pasien. Selama ini yang memenuhi syarat agar tercapai dosis hemodialisis yang ideal adalah antara 200-250 ml/menit. National kidney Foundation (NKF-KDOQI, 2009) menyatakan yang paling tepat adalah $300-400 \mathrm{ml} / \mathrm{menit}$.

Angka kematian pasien yang menjalani hemodialisa rutin di RSUD Indramayu sebanyak 42 orang dalam 1 tahun terakhir. Ada banyak faktor yang menyebabkan kematian pasien yang menjalani hemodialisa, salah satunya mungkin karena adanya perubahan tekanan darah. Sementara hasil survey yang dilakukan penulis terhadap 10 pasien yang sedang menjalani hemodialisa ditemukan sebanyak $7(70 \%)$ pasien mengalami peningkatan tekanan darah, dan sebanyak $3(30 \%)$ pasien mengalami penurunan tekanan darah.

Berdasarkan fenomena tersebut ditemukan adanya variasi perubahan tekanan darah pre dan post hemodialisa. Tujuan dari penelitian ini adalah untuk mengetahui faktor-faktor yang mempengaruhi 
perubahan tekanan darah post hemodialisa.

\section{METODE}

Penelitian ini merupakan penelitian kuantitatif dengan pendekatan cross-sectional. Populasi dari penelitian ini sebanyak 151 pasien GGK yang menjalani terapi hemodialisa dengan jumlah sampel sebanyak 123 responden. Adapun teknik pengambilan sampel menggunakan teknik counsecutive sampling yaitu semua pasien GGK yang menjalani hemodialisa di UPTD RSUD Kabupaten Indramayu yang terpilih berdasarkan kriteria inklusi dan eksklusi yang telah diterapkan (Sugiono, 2016). Adapun kriteria inklusinya meliputi pasien hemodialisa rutin 2 kali seminggu; memiliki IDWG $\leq 6 \%$; usia Pasien $\leq 65$ tahun; dan tidak mengkonsumsi obat antihipertensi. Instrumen yang digunakan adalah lembar observasi dan sphygmomanometer aneroid.

Pengambilan data dilakukan pada waktu yang bersamaan (point time approach), dimana tiap subyek penelitian hanya diteliti satu kali, dan pengukuran variable juga hanya dilakukan sekali saja, yaitu saat pengngambilan data penelitian. Analisa univariat meliputi kategori usia, derajat IDWG, kategori QoB, kategori lama hemodialisa, dan perubahan tekanan darah yang disajikan dalam bentuk tabel distribusi frekuensi. Analisa bivariat menggunakan Uji Pearson Chi-Square.

\section{HASIL}

Penelitian telah dilaksanakan pada bulan Mei 2019 di ruang Hemodialisa UPTD RSUD Kabupaten Indramayu. Hasil penelitian ini meliputi analisa univariat dan analisa bivariat.

\section{Analisa Univariat}

Berikut hasil analisa data karakteristik responden yang berjumlah 123 responden dapat dilihat pada tabel berikut:
Tabel 1. Data Karakteristik Responden

\begin{tabular}{|c|c|c|c|}
\hline No & Karakteristik & $\mathrm{F}$ & $\%$ \\
\hline 1. & $\begin{array}{l}\text { Usia } \\
\text { Muda } \\
\text { Tua }\end{array}$ & $\begin{array}{l}53,0 \\
70,0 \\
\end{array}$ & $\begin{array}{l}43.1 \\
56.9 \\
\end{array}$ \\
\hline 2. & $\begin{array}{l}\text { Jenis kelamin } \\
\text { Laki-laki } \\
\text { Perempuan }\end{array}$ & $\begin{array}{l}64,0 \\
59,0 \\
\end{array}$ & $\begin{array}{l}52,0 \\
48,0 \\
\end{array}$ \\
\hline 3. & $\begin{array}{l}\text { Derajat IDWG } \\
\text { Ringan } \\
\text { Sedang } \\
\text { Berat } \\
\end{array}$ & $\begin{array}{l}57,0 \\
42,0 \\
24,0\end{array}$ & $\begin{array}{l}46.3 \\
34.1 \\
29,5 \\
\end{array}$ \\
\hline 4. & $\begin{array}{l}\text { Quick of blood } \\
\text { Rendah } \\
\text { Tinggi }\end{array}$ & $\begin{array}{l}74,0 \\
49,0\end{array}$ & $\begin{array}{l}60.2 \\
39.8\end{array}$ \\
\hline 5. & $\begin{array}{l}\text { Pekerjaan } \\
\text { Bekerja } \\
\text { Tidak bekerja }\end{array}$ & $\begin{array}{l}78,0 \\
45,0\end{array}$ & $\begin{array}{l}63.4 \\
36.6\end{array}$ \\
\hline 6. & $\begin{array}{l}\text { Lama menjalani HD } \\
\text { Baru } \\
\text { Lama }\end{array}$ & $\begin{array}{l}58.0 \\
65.0\end{array}$ & $\begin{array}{l}47.2 \\
52.8\end{array}$ \\
\hline 7. & $\begin{array}{l}\text { Perubahan TD } \\
\text { Menurun } \\
\text { Tetap } \\
\text { Meningkat }\end{array}$ & $\begin{array}{l}64,0 \\
15.0 \\
44,0\end{array}$ & $\begin{array}{l}52.0 \\
12.2 \\
35.8\end{array}$ \\
\hline
\end{tabular}

Berdasarkan data diatas diketahui sebanyak 70 (56.9\%) responden termasuk dalam kategori kelompok umur tua, sebanyak $64(52 \%)$ responden berjenis kelamin laki-laki, sebanyak 57 (46.3\%) responden memiliki IDWG dalam kategori ringan $(<4 \%)$, sebanyak 74 $(60,2 \%)$ responden dengan dosis QoB rendah $(<200$ $\mathrm{ml} /$ menit), sebanyak 78 (63.4\%) responden bekerja, sebanyak 65 (52.8\%) responden sudah lama menjalani hemodialisa (> 2 tahun), dan sebanyak 64 (52.8\%) responden mengalami penurunan tekanan darah post hemodialisa.

\section{Analisa Bivariat}

Uji korelasi dalam penelitian ini menggunakan uji Pearson Chi-square. Faktor yang dianalisis meliputi usia, interdialytic weight gai, quick of blood, dan lama menjalani hemodialisa. Adapun dapat dilihat pada tabel berikut: 
Tabel 2. Analisis faktor-faktor yang Berhubungan dengan Perubahan Tekanan Darah Post Hemodialisa sehingga akan mempengaruhi hemodinamika dan sistem kardiovaskuler.

\begin{tabular}{|c|c|c|c|c|c|c|c|c|c|c|}
\hline \multirow{3}{*}{ Variabel } & \multirow{3}{*}{ Kategori } & \multicolumn{6}{|c|}{ Tekanan Darah } & \multirow{2}{*}{\multicolumn{2}{|c|}{ Total }} & \multirow{3}{*}{ P Value } \\
\hline & & \multicolumn{2}{|c|}{ Menurun } & \multicolumn{2}{|c|}{ Tetap } & \multicolumn{2}{|c|}{ Meningkat } & & & \\
\hline & & $\mathrm{F}$ & $\%$ & $\mathrm{~F}$ & $\%$ & $\mathrm{~F}$ & $\%$ & $\mathrm{~F}$ & $\%$ & \\
\hline \multirow[t]{3}{*}{ Usia } & Muda & 28 & $52,8 \%$ & 8 & $15,1 \%$ & 17 & $32,1 \%$ & 53 & $100,0 \%$ & \multirow{3}{*}{0,604} \\
\hline & Tua & 36 & $51,4 \%$ & 7 & $10,0 \%$ & 27 & $38,6 \%$ & 70 & $100,0 \%$ & \\
\hline & Total & 64 & $35,8 \%$ & 15 & $12,2 \%$ & 44 & $35,8 \%$ & 123 & $100,0 \%$ & \\
\hline \multirow[t]{4}{*}{ IDWG } & Ringan & 25 & $43,9 \%$ & 10 & $17,5 \%$ & 22 & $38,6 \%$ & 57 & $100,0 \%$ & \multirow{4}{*}{0,144} \\
\hline & Sedang & 28 & $66,7 \%$ & 2 & $4,8 \%$ & 12 & $28,6 \%$ & 42 & $100,0 \%$ & \\
\hline & Berat & 11 & $45,8 \%$ & 3 & $12,5 \%$ & 10 & $41,7 \%$ & 24 & $100,0 \%$ & \\
\hline & Total & 64 & $35,8 \%$ & 15 & $12,2 \%$ & 44 & $35,8 \%$ & 123 & $100,0 \%$ & \\
\hline \multirow[t]{3}{*}{ QoB } & Rendah & 38 & $51,4 \%$ & 8 & $10,8 \%$ & 28 & $37,8 \%$ & 74 & $100,0 \%$ & \multirow{3}{*}{0,767} \\
\hline & Tinggi & 26 & $53,1 \%$ & 7 & $14,3 \%$ & 16 & $32,7 \%$ & 49 & $100,0 \%$ & \\
\hline & Total & 64 & $35,8 \%$ & 15 & $12,2 \%$ & 44 & $35,8 \%$ & 123 & $100,0 \%$ & \\
\hline \multirow[t]{3}{*}{ Lama HD } & Baru & 32 & $55,2 \%$ & 5 & $8,6 \%$ & 21 & $36,2 \%$ & 58 & $100,0 \%$ & \multirow{3}{*}{0,506} \\
\hline & Lama & 32 & $49,2 \%$ & 10 & $15,4 \%$ & 23 & $35,4 \%$ & 65 & $100,0 \%$ & \\
\hline & Total & 64 & $35,8 \%$ & 15 & $12,2 \%$ & 44 & $35,8 \%$ & 123 & $100,0 \%$ & \\
\hline
\end{tabular}

Berdasarkan tabel diatas dapat diketahui sebanyak 123 responden penyakit ginjal kronik yang menjalani terapi hemodialisa sebanyak 108 (87,8\%) mengalami perubahan tekanan darah post hemodialisa, baik mengalami penurunan maupun peningkatan. Berdasarkan analisa data diketahui faktor usia, IDWG, QoB, dan lama menjalani HD tidak berhubungan dengan perubahan tekanan darah post hemodialisa $(p$ value $>0,05)$.

\section{PEMBAHASAN}

Hemodialisa merupakan terapi pengganti ginjal yang banyak dipilih. Namun terapi ini bukan tanpa komplikasi. Komplikasi yang sering muncul adalah perubahan tekanan darah selama waktu hemodiaisa, baik tekanan darah meningkat (hipertensi), maupun tekanan darah menurun (hipotensi).

Perubahan tekanan darah pada pasien hemodialisa dipengaruhi oleh mesin hemodialisa saat terjadi proses dialisis. Tindakan hemodialisa bertujuan untuk membersihkan sampah metabolik dan mengurangi retensi cairan dalam tubuh, ketika proses hemodialisa, darah dalam tubuh pasien akan ditarik atau dialirkan kedalam mesin hemodialisa, darah akan difiltrasi atau dipisahkan dari zat toksik yang ada dalam darah pasien, ketika darah sudah difiltrasi darah akan dialirkan kembali kedalam tubuh. Proses hemodialisa akan menyebabkan volume cairan dalam tubuh berkurang
Hasil penelitian menunjukkan dari 123 responden penyakit ginjal kronik yang menjalani terapi hemodialisa mengalami perubahan tekanan darah post hemodialisa, yaitu sebanyak 64 (52\%) responden mengalami penurunan tekanan darah, sebanyak $44(35,8 \%)$ responden mengalami peningkatan tekanan darah, dan sebanyak $15(12,2 \%)$ responden tidak mengalami perubahan tekanan darah pada periode post hemodialisa. Berdasarkan hasil tersebut ditemukan sebagian besar responden mengalami penurunan tekanan darah post hemodialisa.

Sesuai dengan hasil studi literature yang dilakukan oleh Heerspink, et al. (2009) menemukan bahwa penurunan tekanan darah selama hemodialysis adalah sebesar 4-5 mmHg. Namun beda hasil penelitian yang dilakukan oleh Van Buren, et al (2011) yang menyimpulkan ada perbedaan tekanan darah pre dialisa dengn post dialisa, yaitu mengalami kenaikan $(\mathrm{p}=0,005)$.

Menurut Georgianos and Agarwal, (2017) mengatakan bahwa adanya fenomena paradoks dimana tekanan darah yang lebih rendah (menurun) berkaitan dengan peningkatan mortalitas. Sedangkan peningkatan tekanan darah justru menurunkan angka mortalitas pada pasien interdialisis.

Sementara faktor yang diduga mempengaruhi perubahan tekanan darah post hemodialisa, yaitu usia, 
IDWG, QoB, dan lama waktu menjalani hemodialisa, terbukti tidak berhubungan dengan perubahan tekanan darah post hemodialisa ( $p$ value $>0,05 ; 95 \%$ CI). Faktor usia ( $p$ value $=0,604 ; 95 \% \mathrm{CI})$, IDWG $(p$ value $=0,144 ; 95 \% \mathrm{CI}), \mathrm{QoB}$ ( $p$ value $=0,767 ; 95 \%$ $\mathrm{CI}$ ), dan lama menjalani hemodialisa ( $p$ value $=0,506$; $95 \%$ CI). Berdasarkan hasil tersebut menunjukkan bahwa perubahan tekanan darah post hemodialisa tidak dipengaruhi oleh faktor usia, IDWG, QoB, dan lama waktu menjalani hemodialisa. Artinya ada faktor lain yang mempengaruhi perubahan tekanan darah post hemodialisa.

Penelitian lain yang hasilnya sejalan dengan penelitian ini adalah penelitian yang dilakukan oleh Naysilla dan Partiningrum, (2012) yang menemukan bahwa faktor usia, IDWG, URR, RRF, dan lama hemodialysis tidak berhubungan dengan kejadian hipertensi intradialitik ( $p$ value $>0,05 ; 95 \% \mathrm{CI}$ ). Hasil penelitian tersebut belum dapat disimpulkan bahwa faktor faktor usia, IDWG, URR, RRF, dan lama hemodialysis menjadi faktor risiko hipertensi intradialitik karena banyak keterbatasan yang ditemukan saat melakukan penelitian, salah satunya tidak terpenuhinya jmlah sampel minimal.

Faktor lain yang menyebabkan perubahan tekanan darah pasca menjalani terapi hemodialisa adalah respon renin dan stres. Stres yang dialami pasien pasien yang menjalani terapi hemodialisa juga berpengaruh terhadap perubahan tekanan darah post hemodialisa. Ketika seseorang mengalami ansietas, takut, nyeridan stres emosi mengakibatkan stimulasi simpatik yang meningkatkan frekuensi darah, curah jantung dan tahanan vaskuler perifer. Efek stimulasi simpatik ini dapat meningkatkan tekanan darah, sehingga dapat terjadi perubahan tekanan darah pada pasien hemodialisa.

Ketika terjadi peningkatan tekanan darah post hemodialisa hal itu bisa terjadi karena respon dari enzim angiotensin terlalu aktif terhadap penurunan volume darah dalam tubuh dimana peran dari enzim angiotensin adalah hormon yang mengatur tekanan darah dan keseimbangan cairan dalam tubuh. Menurut Klabunde (2007), ketika volume darah rendah, sel-sel juxtaglomerular di ginjal mengeluarkan renin. Renin merangsang produksi angiotensin I, yang kemudian diubah menjadi angiotensin II enzyme Angiotensin Converting Enzyme (ACE) didalam paru- paru. Angiotensin II menyebabkan pembuluh darah mengerut, sehingga tekanan darah meningkat.

Pada pasien yang mengalami penurunan tekanan darah hal itu dapat terjadi karena ketika proses hemodialisa, darah dalam tubuh pasien akan ditarik atau dialirkan kedalam mesin hemodialisa, darah akan difiltrasi atau dipisahkan dari zat toksik yang ada dalam darah pasien, ketika darah sudah difiltrasi darah akan dialirkan kembali kedalam tubuh. Proses hemodialisa akan menyebabkan volume cairan dalam tubuh berkurang sehingga akan mempengaruhi hemodinamika dan sistem kardiovaskuler pasien yaitu kerja jantung akan kembali normal dalam memompa cairan maka hal tersebut akan menurunkan tekanan darah pasien setelah menjalani terapi hemodialisa (Black \& Hawk, 2014)

Berdasarkan hasil penelitian diketahui sebanyak 15 $(12,2 \%)$ responden tidak mengalami perubahan tekanan darah, menunjukkan bahwa tidak selamanya pasien yang menjalani terapi hemodialisa mengalami perubahan tekanan darah. Perubahan tekanan darah dapat terjadi karena beberapa faktor antara lain dipengaruhi viskositas darah (kekentalan darah). Viskositas darah dipengaruhi oleh protein plasma dan jumlah sel darah yang berada di dalam aliran darah. Makin pekat cairan maka makin besar kekuatan yang diperlukan untuk mendorongnya melalui pembuluh darah.

Pemberian cairan seperti plasma atau garam akan menyebabkan tekanan naik lagi. Tindakan ini dilakukan terhadap pasien yang mengalami penurunan tekanan darah yang signifikan atau pada pasien yang mengalami hipotensi. Bila terdapat pemantauan dan tindakan yang benar pada saat proses hemodialisa, maka dapat mempertahankan tekanan darah pasien hemodialisa (Pearce, 2010).

Dosis QoB pada penelitian ini rata-rata $200 \mathrm{ml} /$ menit. Diketahui sebanyak $74(60,2 \%)$ responden memiliki dosis QoB $<200 \mathrm{ml} /$ menit. Secara fisologis semakin tinggi nilai QoB makan semakin cepat proses penyaringan sampah metabolik dalam tubuh. Maka volume cairan yang hilang dalam tubuh akan semakin cepat (Kallenbach, Gutch, Stoner \& Corea, 2005). Keadaan tersebut akan berpengaruh terhadap hemodinamika tubuh dan perubahan tekanan darah pasien, ketika volume cairan dalam tubuh tidak 
berlebih, maka kerja jantung menjadi normal kembali, sehingga menyebabkan penurunan tekanan darah pada pasien hemodialisa.

\section{KESIMPULAN}

1. Sebanyak $70(56.9 \%)$ responden termasuk dalam kategori kelompok umur tua, sebanyak 57 (46.3\%) responden memiliki IDWG dalam kategori ringan $(<4 \%)$, sebanyak $74(60,2 \%)$ responden dengan dosis QoB rendah ( $<200 \mathrm{ml} / \mathrm{menit})$, dan sebanyak 65 $(52.8 \%)$ responden sudah lama menjalani hemodialisa (> 2 tahun)

2. Sebanyak $64(52.8 \%)$ responden mengalami penurunan tekanan darah post hemodialisa.

3. Faktor usia ( $p$ value $=0,604 ; 95 \% \mathrm{CI})$, IDWG $(p$ value $=0,144 ; 95 \% \mathrm{CI}), \mathrm{QoB}$ ( $p$ value $=0,767 ; 95 \%$ $\mathrm{CI}$ ), dan lama menjalani hemodialisa ( $p$ value $=0,506$; 95\% CI) tidak berhubungan dengan perubahan tekanan darah post hemodialisa ( $p$-value $>0,05)$.

\section{SARAN}

\section{Bagi rumah sakit}

Perawat diharapkan untuk senatiasa melakukan monitoring perubahan tekanan darah selama interdialisis, terutama yang mengalami penurunan tekanan darah karena meningkatkan risiko komplikasi pasca hemodialisa.

\section{Bagi Penelitian Lain}

Diharapkan dapat melakukan penelitian lebih lanjut dan mendapatkan metode yang tepat untuk menemuka faktor dominan yang mempengaruhi perubahan tekanan darah post hemodialisa.

\section{DAFTAR PUSTAKA}

Assimon, M.M and Flythe, J. E. (2015). Intradialytic Blood Pressure Abnormalities: The Highs, The Lows and All That Lies Between. American Journal of Nephrology, 42, 337-350. https://doi. org/10.1159/000441982

Badan Penelitian dan Pengembangan Kesehatan. (2018). Hasil Utama Rikesdas 2018.

Black, J., \& Hawk, J. H. (2014). Keperawatan medikal bedah: Manajemen klinis untuk hasil yang diharapkan. Elsevier.

Daugirdas, J.T., Blake, P.B., \& Ing, T. S. (2007).
Physiologic principles and urea kinetic modeling: Handbook of dialysis fourth edition. Lippincott Williams \& Wilkins.

Flythe, J.E. Kunaparaju, S., Dinesh, K., Kathriyn, T., et al. (2012). Factors Associated With Intradialytic Systolic Blood Pressure Variability. American Journal of Kidney Diseases, 59(3), $409=418$.

Georgianos, P.I and Agarwal, R. (2017). Blood Pressure and Mortality in Long-Term HemodialysisTime to Move Forward. American Journal of Hipertention., 30(3), 211-222. https://doi. org/10.1093/ajh/hpw114

Heerspink, H. J. L. et all. (2009). Effect of lowering blood pressure on cardiovascular events and mortality in patients on dialysis: a systematic review and meta-analysis of randomised controlled trials. The Lancet, 373(9668), 1009-1015.

Indonesian Renal Registry (IRR). (2016). Laporan data IRR tahun 2016.

IRR. (2018). 11th Report Of Indonesin Renal Registry 2018Registry, In.

Kallenbach, J.Z., Gutch, C.F., Stoner, M.H.,\& Corea, A. L. (2005). Review of hemodialysis for nursing and dialysis personnel (7ed.). Elsevier Saunders.

Klabunde, R. E. (2007). Cardiovascular physiology concept: renin-angiotensinaldosteron.

Naysilla, A.M dan Partiningrum, D. L. (2012). Faktor Risiko Hipertensi Intradialitik Pasien Penyakit Ginjal Kronik. Undip.

NKF-KDOQI. (2009). Clinical practice guidelines on hypertension and antihypertensive agents in chronic kidney disease, Guideline 12.

Pearce, E. (2010). Anatomi dan Fisiologi Untuk Paramedis. PT Gramedia Pustaka Utama.

PERNEFRI. (2008). Pedoman Pelayanan Hemodialisis di Sarana pelayanan Kesehatan. Direktorat Jendram Bina pelayanan Medik Depkes RI.

Saferi, A \& Mariza, Y. (2013). Keperawatan medikal bedah (Keperawatan Dewasa). Nuha Medika.

Smeltzer, S., C., dan Bare, G. (2015). Buku ajar Keperawatan medikal Bedah Brunner \& Suddarth. EGC.

Sugiono. (2016). Metode penelitian pendidikan pendekatan kuantitatif, kualitatif, dan R\&D. Alfabeta.

Van Buren, P.N., Kim, C., Toto, R. and Inrig, J. K. (2011). Intradialytic Hypertension and the Association with Interdialytic Ambulatory Blood Pressure. Clinical Journal of the American 
Society of Nephrology, 6, 1684-1691. https://doi. org/10.1097/MNH.0b013e32834db3e4.

Van Buren, P. N. (2017). Pathophysiology and Implications of Intradialytic Hypertension. Curren Opinion in Nephrology and Hypertension, 26(4), 303-310. https://doi.org/10.1097/ MNH.0000000000000334 